\title{
ОСОБЕННОСТИ \\ ОРГАНИЗАЦИОННО-ПЕДАГОГИЧЕСКОЙ ДЕЯТЕЛЬНОСТИ ПРЕПОДАВАТЕЛЯ РУССКОГО КАК ИНОСТРАННОГО В МЕДИЦИНСКОМ ВУЗЕ
}

\section{Мирзоева В.М., Аксенова Е.Д., Кузнецова А.А., Ткачева Р.А.}

Федеральное государственное бюджетное образовательное учреждение высшего образования «Тверской государственный медицинский университет» Министерства здравоохранения

Российской Федерации, г. Тверь, Российская Федерация

Данная статья посвящена основным аспектам формирования толерантного сознания иностранных студентов-медиков, которые неразрывно связаны с лингвокультурной адаптацией. Анализ данной проблемы, проведенный авторами в рамках этого направления, свидетельствует о том, что успешность работы преподавателя русского языка как иностранного зависит не только от изучения языка параллельно с изучением человека как языковой личности, но и от того, насколько творчески преподаватель использует способы педагогического управления данным лингвоэтносоииумом. Важную роль в медицинском вузе при этом играет связь преподавания русского языка как иностранного с получаемой спечиальностью, в связи с чем язык медицинской науки становится, во-первых, ведущим мотивирующим фактором в обучении русскому языку как неродному, во-вторых, расширяет границы профессиональной коммуникации, способствует инкультурации иноязычного человека в российскую действительность, а значит, облегчает решение социопсихологических проблем. Данные вопросы авторы статьи рассматривают, опираясь на многолетний опыт педагогической работы с иностранными обучающимися в медицинском вузе.

Ключевые слова: формирование толерантного сознания; иностранные обучающиеся; медичинский вуз; поликультурная образовательная среда; опыт педагогов-лингвистов; навыки педагогического управления. 


\section{SPECIAL FEATURES OF THE PEDAGOGICAL STRATEGY IN THE TEACHING OF FOREIGN STUDENTS IN THE MEDICAL UNIVERSITY}

\section{Mirzoyeva V.M., Axenova E.D., Kuznetsova A.A., Tkacheva R.A.}

Tver State Medicine University, Tver, Russian Federation

This article is devoted to examination of special features of pedagogical strategy in teaching Russian language as foreign to students in a medical university. Exploring the role of a personality of Russian language teacher in the adaptation of a foreign student to the multicultural educational environment the authors pay special attention to the importance of establishment a tolerant mindset of foreign students as the adaptation to new sociocultural and educational system is impossible without it. Working experience of Russian language teachers indicates that the establishment of a tolerant language personality of a medical student is affected by knowledge of Russian fiction, learning formula of speech etiquette and getting knowledge of cultural and country-specific reality of modern life in Russia. However the commitment to professional communication of a foreign student in the realities of medical university makes learning language of specialization the main motivating factor both in learning Russian language itself and in establishment of a new multicultural field for a foreign person which has a tolerance to another person's opinion, behavior norms which are different to those in foreign countries, different beliefs, unusual forms of expressing different ideas as necessary qualities.

Keywords: establishment of a tolerant mindset; foreign students; medical university; multicultural educational environment; experience of teaching linguists; skills of pedagogical management.

Проблема адаптации иностранных обучающихся привлекает внимание многих исследователей. Не вызывает сомнения тот факт, что человек, оказавшийся в новой культурной среде, нуждается в овла- 
дении новыми навыками социального поведения, которые позволяют ему быть успешным, и ведущую роль в этом процессе играет личность самого педагога, в данном случае преподавателя русского как иностранного.

Учитывая профессионализм российских педагогов, преподающих в высшей школе, остановимся, главным образом, на некоторых аспектах формирования толерантного сознания иностранных обучающихся-медиков и роли социокультурной среды в процессе инкультурации иноязычного человека в российскую действительность. Безусловно, в современной русистике значительно расширились концептуальные рамки исследований: усилился интерес к проблемам этнопсихологического и этнокультурного характера, которые рассматриваются чаще всего в сопоставительном аспекте. Общим достоянием лингводидактики является опыт изучения проблем межъязыковой и межкультурной коммуникации, накопленный в медицинских вузах России. Неслучайно, что именно в этой сфере начали активно обсуждаться вопросы социально-психологической и лингвокультурной адаптации, процессов вторичной аккультурации языковой личности. Лингвокультурная адаптация рассматривается как процесс вхождения в ценностно-смысловое поле иной социокультурной среды через обучение русскому языку, изучение русской культуры, овладение языком медицинской специальности.

Более полвека ведет обучение иностранных граждан из разных регионов мира кафедра русского языка Тверского государственного медицинского университета. В настоящее время здесь получают образование представители дальнего зарубежья: арабских, африканских стран, а также стран Азии (самыми представительными являются землячества Индии и республики Шри-Ланка) Приметой нового времени является увеличение количества обучающихся из стран ближнего зарубежья - СНГ.

«Иностранцы, впервые приехавшие в Россию, сталкиваются с проблемами, которые не всегда связаны с языковыми трудностями» $[1$, c. 70$]$. Многие из них возникают в процессе адаптации к новой социокультурной и образовательной системе. И в этой новой по- 
ликультурной образовательной среде одним из ведущих элементов определения педагогической стратегии становится формирование толерантного сознания у иностранных обучающихся. В связи с этим преподавателю необходимы специальные знания об особенностях поведения людей, сопоставительные исследования национальноментального сознания представителей различных культур, основанные на знании этнопсихологии, социальных дисциплин и др.

Общеизвестно, что в поликультурной образовательной среде одним из ключевых является понятие толерантности. С позиции лингводидактики толерантность понимается как терпимость к чужим мнениям, идеям, к непривычным формам выражения в языке какого-либо смысла, к непринятым в родной культуре нормам поведения и т.п. Говоря о поликультурной образовательной среде, необходимо учитывать интернациональный характер студенческой группы, где каждый учащийся вынужден адаптироваться к культурным ценностям и верованиям инокультурных членов группы. Состав учебных групп в Тверском государственном медицинском университете отличается своеобразным колоритом: полиэтничностью, разноязычностью (представлены англо-, франкофоны, испано-, арабоговорящие и др.), идеологической, религиозной многовариативностью этнокультур, что, несомненно, усиливает социокультурный дискомфорт.

Не претендуя на полноту освещения обозначенных проблем, обобщим наблюдения нашей практики, позволяющие составить некоторое представление о готовности представителей различных этнокультур к адекватному восприятию культурно-страноведческой информации и социально-культурной адаптации в новой среде.

Многие годы кафедра работает с индийскими учащимися. Охарактеризовать национально-культурные особенности поведения индийских студентов в русскоязычной среде довольно сложно, поскольку индийское землячество представлено множеством субкультур. Как и Россия, Индия является обществом с множеством этносов, языков и культур, и поэтому многие проблемы, в том числе межэтнических отношений, актуальны для обеих стран. Наши наблюдения показывают, что в учебной и бытовой среде индийцы чаще всего обособля- 
ются по религиозным признакам. Кроме того, в лингвокультурном плане среди индийских студентов выделяются, с одной стороны, гуманитарные личности, делающие большие успехи в изучении русского языка и русской культуры, с другой стороны, прагматики, достаточно сдержанные к восприятию чужой культуры. Следует также учитывать, что высокая концентрация представителей данной этнокультуры делает их общение самодостаточным в пределах своей диаспоры, что может отрицательно влиять на языковую подготовку. Работа с индийскими учащимися имеет еще один важный, на наш взгляд, аспект: многие студенты, получив высшее медицинское образование в России, уезжают в третьи страны, поэтому нам небезразлично, где и как «слово наше отзовется» [2, с. 242].

Нередко индийские выпускники оказывают переводческие услуги, чему способствует знание русского языка и культурно-страноведческих реалий современной российской жизни. В работе с представителями Индии, Шри-Ланки, Непала необходимо учитывать особенности восточного менталитета. Преподаватели и методисты, работающие со студентами из стран Азии, отмечают, что в этих культурах особой добродетелью считается сдержанность в общении, и ученики привыкли говорить только после учителя. Культура с традициями буддизма утверждает, что знания, истина и мудрость приходят в тихом молчании. Поэтому такие моменты русского речевого поведения, как наступательная манера общения, быстрый темп речи, многословие могут вызывать непонимание представителей восточных культур.

Традиционно трудными для межличностного общения являются формулы речевого этикета. Этикет - явление национальное. То, что считается вежливым у одного народа, может быть истолковано как невежливое отношение к собеседнику у другого. Согласно опросу, особенно затруднительным для студентов из разных стран является принятое в русской традиции обращение по имени и отчеству, так как в других культурах существуют другие формы обращения. Так, студенты из Индии, Шри-Ланки и других стран предпочитают обращение к преподавателю: «мадам», «сэр», «преподаватель», по- 
скольку обращение по имени и отчеству считают неуважительным. Кроме этого, сложность вызывают фонетико-грамматические особенности русских имен.

Немалые трудности в правильном произношении имен иностранцев испытывают и сами преподаватели, поскольку во многих языках и культурах существует очень сложная система употребления личных имен. В межличностном общении важно учитывать, что любому из нас небезразлично, как звучит свое имя. Об этом говорил Д. Карнеги: «Помните, что имя человека - это самый сладостный и самый важный для него звук на любом языке» [3, с. 95]. Следует подчеркнуть, что основным средством общения в интернациональной группе является русский язык и от уровня сформированности языковой и коммуникативной компетенций иностранцев зависит успешность контактов с носителями языка в учебной и профессиональной сферах, что особенно важно для студентов-медиков. В процессе взаимопонимания между говорящими большую роль играет фонетическое оформление речи.

Общий опыт педагогов-лингвистов, работающих в иностранной аудитории, свидетельствует о том, что знание общих зон и различий в «картинах мира» лингвокультурных сообществ способствует взаимному восприятию этносами друг друга. Наряду со специфическими, существуют общечеловеческие ценности (семья, профессия, здоровье и др.). Безусловно, ориентация на общечеловеческие ценности в процессе изучения языка и медицины в каждой интернациональной группе ведет к сближению ее представителей. Изучение языка и овладение профессией врача идет параллельно с изучением человека как языковой личности, отражающей в себе особенности национально-культурного мышления, ценностных ориентиров и др. Именно в русле такого понимания в иностранной аудитории обсуждаются проблемы, связанные с образом жизни человека (здоровый образ жизни, вредные привычки и др.).

Формирование толерантной языковой личности иностранного студента во многом способствует знакомство с художественной литературой нашей страны, которая позволяет показать культу- 
ру России как культуру полиэтнического государства. Эффективность преподавателя русского как иностранного во многом зависит от того, насколько творчески он использует информацию о межкультурных связях народов, интересующую конкретно данную аудиторию. Например, формированию поликультурного поля обучающихся способствует ознакомление с деятельностью известных писателей, врачей, ученых, которые внесли большой вклад в общемировую культуру (Авиценна, Рабиндранат Тагор, Махатма Ганди, Лев Толстой и др.)

Связь процесса преподавания русского языка с получаемой специальностью, на наш взгляд, особенно актуальна для медицинских вузов. Именно язык специальности для студента-медика является главным мотивирующим фактором в процессе обучения русскому языку как неродному. Специфика медицинской науки, характеризующей постоянные, закономерные качества и свойства организма человека определяет и выбор лексико-грамматических и синтаксических средств [4, с. 154-161]. Опыт практической работы по обучению иностранных студентов-медиков языку будущей специальности говорит о гораздо большем интересе иностранных студентов к учебным пособиям медико-биологического профиля, чем филологического, и свидетельствует о том, что актуальный в медицинском тексте лексико-грамматический материал изучается глубже и усваивается лучше, чем тот, который нечастотен в текстах медицинского профиля.

Таким образом, поликультурный, полиэтнический состав иностранных студентов-медиков требует от преподавателей, работающих с иностранными обучающимися, не только профессиональных знаний, но и навыков педагогического управления данным лингвосоциумом. Вопрос об использовании педагогических стратегий в обучении русскому языку как иностранному, безусловно, многоаспектен, однако при методически грамотном подходе к его решению возможно интенсифицировать процесс обучения русскому языку как иностранному, сделать его более приближенным к ожиданиям и возможностям обучающихся. 


\section{Список литературы}

1. Баженов Д.В., Иванов А.Г., Мирзоева В.М. Психолого-педагогические факторы успешности подготовки иностранных учащихся в медицинском вузе // Высшее образование в России. 2011. №11. С. 70-76.

2. Тютчев Ф.И. Полное собрание стихотворений / Сост., подгот. текста и примеч. А.А. Николаева. Л.: Сов. писатель, 1987. 448 с.

3. Карнеги Д. Как завоевывать друзей и оказывать влияние на людей. М.: Прогресс, 1991. 240 с.

4. Аксенова Е.Д., Мирзоева В.М., Мирзоева Е.З. Модальность научного (медицинского) текста на материале текстов оториноларингологии // Современные исследования социальных проблем. 2016. №4-1(28). С. 154-161.

\section{References}

1. Bazhenov D.V., Ivanov A.G., Mirzoeva V.M. Psikhologo-pedagogicheskie faktory uspeshnosti podgotovki inostrannykh uchashhikhsya $v$ meditsinskom vuze // Vysshee obrazovanie v Rossii. 2011. №11. S. 70-76.

2. Tyutchev F.I. Polnoe sobranie stikhotvorenij / Sost., podgot. teksta i primech. A.A. Nikolaeva. L.: Sov. pisatel', 1987. 448 s.

3. Karnegi D. Kak zavoevyvat' druzej i okazyvat' vliyanie na lyudej. M.: Progress, 1991. $240 \mathrm{~s}$.

4. Aksenova E.D., Mirzoeva V.M., Mirzoeva E.Z. Modal'nost' nauchnogo (meditsinskogo) teksta na materiale tekstov otorinolaringologii // Sovremennye issledovaniya sotsial'nykh problem. 2016. №4-1(28). S. 154-161. 